\title{
Greenways and Ecological Networks: Concepts, Differences, Similarities
}

\author{
Mara Balestrieri ${ }^{1 *}$ and Amedeo Ganciu ${ }^{2}$ \\ ${ }^{1}$ Department of Agricultural Sciences, University of Sassari, Italy \\ ${ }^{2}$ Department of Architecture and Design (DiAP), Sapienza University of Rome, Italy
}

Submission: October 01, 2017 Published: October 16, 2017

"Corresponding author: Mara Balestrieri, Department of Agricultural Sciences, University of Sassari, Italy, Email: marbal@uniss.it

\begin{abstract}
In recent decades green infrastructure (GI) frameworks have been widely used for developing theoretical and practical models of sustainable land reorganization. Although there is still much confusion regarding various aspects of green infrastructure, since many differing perspectives have generated different definitions that emphasise the complexity of the green infrastructure concept, it is possible to find important differences and common points.
\end{abstract}

Keywords: Green infrastructures; Territorial planning; Environmental planning

opinion

The exponential growth of the urban areas that has characterized the last century has not been accompanied by an equal development in the quality of life of the citizens: environmental problems, poor access to resources and services, marginalization and poverty are common elements in many contemporary metropolitan landscapes [1]. Academic scholars and public operators are trying to find the most effective response devices and strategies for improving urban spaces, with environmental and social regeneration capabilities linked to the heritage of green areas within metropolitan areas [2].

In several international contexts, strategies, plans and policies for environmental protection have long been used [3]. Today, many of these practices are summarized in the ample definition of "green infrastructure" Llausàs \& Roe [4] and could be defined as a "new urban hardware" to convey the local physical and/or social flows Ganciu [5] with multiple purposes such as: improving people's physical and psychological quality of life [6]; creating the right conditions to encourage citizens to adopt healthier lifestyles [7]; promoting economic well-being in the surrounding areas by stimulating the economy and attracting new public and private investments Serret et al. [8]. creating a more stable and balanced historical and environmental context in which social and cultural landscapes can be created Ribeiro \& Barao [9]; interacting with the logistical systems of goods and people with other transport networks Rekittke \& Lin [10]; Benedict \& McMahon[11]; contributing to climate change adaptation and mitigation [12].

In particular, these "renewed" strategies are being applied in post-industrial realities in economic and social decline where the tensions generated by the lack of relational spaces, which are necessary elements to extend the rights and ability of people to access the city and its opportunities, are stronger Mathey et al. [13].

From the first experiments by Ebenezer Howard in the United Kingdom and Frederick Law Olmest in the US Llausàs \& Roe [4], the increasing use of green infrastructures in different situations and heterogeneous projects have created a wide range of design styles, which differ according to context, scale of the project, objectives and strategies Ahern [14]; Ecological Network for EU and Green Systems in the Balkans, Greenways in the USA, Biodiversity Corridors in the Philippines and Urban Greening in Singapore are just a few examples Fábos \& Ryan [15] (Table1). 


\section{Agricultural Research \& Technology: Open Access Journal}

Table 1: Source Ahern [14] the context can be urban, fringe, rural or natural; the extension of the project can vary from a local level to the macrocontinental order structures Jongman [3], Jones-Walters; its objectives can be ecological, anthropogenic, cultural, recreational or mixed.

\begin{tabular}{|c|c|c|c|}
\hline Definition & Area & $\begin{array}{c}\text { Functions: Biotic, Cultural, } \\
\text { Multifunctional }\end{array}$ & $\begin{array}{c}\text { Scale: Continental, Nazional, } \\
\text { Regional, Local }\end{array}$ \\
\hline Ecological Networks & Europe & B & C,N,R,L \\
\hline Habitat Networks & Europe/America & B & C,N,L, R,L \\
\hline Ecological Infrastructure & Europe & B & N,R,L \\
\hline Greenways & America & B, C, M & R,L \\
\hline Wildlife Corridors & America & B & R,L \\
\hline Riparian Buffer & Europe/America & B, M & R,L \\
\hline EcologicalCorridors & America & B & $\mathrm{R}, \mathrm{L}$ \\
\hline EnvironmentalCorridors & America & C & $\mathrm{R}, \mathrm{L}$ \\
\hline Greenbelts & Europe/America & B & $\mathrm{R}, \mathrm{L}$ \\
\hline LandscapeLinkages & America & & \\
\hline
\end{tabular}

There are many similarities because they use the same scientific basis to support these projects Opdam etal. [16]; Llausàs \& Roe [4]. The challenges of sustainability have demonstrated the need for dialogue between ecologists and planners concerning landscape ecology and ecological planning and that biophysical and socio-cultural information should be used to assess the opportunities and costs of the project Steiner [17]. All types of green infrastructure have their scientific foundation in the biological disciplines, landscape ecology and network analysis; the former are used to understand the impacts of anthropic activities on the natural environment McKinney [18]; landscape ecology describes the effects of landscape fragmentation Farina [19]; network analysis provides us with information on the best risk articulation of these projects in order to ensure maximum connectivity [20].

In particular, studies concerning "biogeography" and the "meta population theory" MacArthur \& Wilson, [21] as tools for providing space consistency between the conservation requirements of nature and territorial development Ahern [14], prevailed during the 1970s and 1980s of the last century and are still the basis for designing numerous green infastructures Robinson [22]; Walmsley [23]. According to these approaches, if a place does not have adequate conditions for the survival of a species, this species will tend to move to another place which is more suitable; conversely species living in an environment that offers many opportunities in terms of resources or energy will tend to occupy it entirely Kennedy et al. [24].

The key elements of these theories are the extension of the area in which the species lives with which it is possible correlate the amount of available resources, the distance between these areas and the presence of corridors and/or barriers that may prevent the movement of the species between two areas Opdam [16]. Two of the most widespread green infrastructure solutions are the European ecological networks and the American greenways. The former can be defined as a set of unified ecosystems within a spatial configuration consistent with the context that assures the movement of organisms or energy and interacts with the matrices of the landscape in which they are placed Opdam et al. [16], while the American Greenways rapidly spread across the USA Flink \& Searn [25] and then into several European countries Ribeiro \& Barao [9], Turner [26] that are indicated in the publication "Greenways for America" Little [27] as an interconnected system of linear elements that are protected, managed and developed in order to reap ecological, cultural and historical benefits; or a communication system for non-motorized vehicles to connect people with landscape resources or daily activities both in urban and extra urban areas President's Commission on Americans Outdoors [28]; Toccolini et al. [29]. Ecological networks can be used for multiple purposes Jongman [3], Ahern [14] but as the name suggests, they mainly concern biological processes and how to consider them within sustainable landscape development policies Opdam et al. [16].

By contrast, the greenways category has a more multifunctional approach therefore three classes can be identified within this category: ecological, recreational and cultural historical Fabos [15], Fumagalli \& Toccolini [30]. Their proliferation could be due to the need to meet the multifunctional demand expressed by contemporary metropolis Meerow \& Newell [31]. Existing literature shows that there are many overlaps between ecological network concepts and greenways Konkoly-Gyurò \& Nagy [32]. In fact, in both cases, it is necessary to ensure the freedom of movement of both people and animals; however, there are also some slight differences.

While ecological networks are realized according to a reticular system composed of various elements and shapes, the greenways are based almost exclusively on linear systems which is their most distinguishing feature. It is important to note that in the ecological network there is often natural flora in the greenway it may also be absent as in some corridors that cross some European historical centers Turner [33]. The ways of implementing greenways may vary according to the context in which they are located. In North America these projects are often realized to reap ecological benefits by incorporating rivers or forests. This is possible thanks to the low population density of the American continent Benedict \& McMahon [2]. 
While Europe's high level of urbanization means that green infrastructures are often developed in urban or rural areas Jongman \& Pungetti [34]. In conclusion, paradoxically it is reasonable to say that American greenways are much more similar to European ecological networks than their European variant [35].

\section{References}

1. UNHSP-United Nations Human Settlements Programme, (2016) World Cities Report. UNHSP, Nairobi, Kenya.

2. Huang L, Wu J, Yan L (2015) Defining and measuring urban sustainability: a review of indicators. Landscape ecology 30(7): 11751193.

3. Jongman RHG (1995) Nature conservation planning in Europe: developing ecological networks. Landscape and urban planning 32(3): 169-183.

4. Llausàs A, Roe M (2012) Green infrastructure planning: Cross-national analysis between the north east of England (UK) and Catalonia (Spain). European planning studies 20(4): 641-663.

5. Ganciu A (2017) Infrastructure verdi e nuove visioni urbane. In: Ippolito AM (Eds.), Nature Urbane per la città futura, a cura di pag. Franco Angeli Edizioni, Milano, pp. 62-68.

6. Wolch JR, Byrne J, Newell JP (2014) Urban green space, public health, and environmental justice: The challenge of making cities just green enough. Landscape and Urban Planning 125: 234-244.

7. Carpenter M (2013) From healthful exercise to nature on prescription: The politics of urban green spaces and walking for health. Landscape and Urban Planning 118: 120-127.

8. Serret H, Raymond R, Foltête JC, Clergeau P, Simon L, et al. (2014) Potential contributions of green spaces at business sites to the ecological network in an urban agglomeration: The case of the Ile-deFrance region, France. Landscape and Urban Planning 131: 27-35.

9. Ribeiro L, Barao T (2006) Greenways for recreation and maintenance of landscape quality: five case studies in Portugal. Landscape and urban planning 76(1): 79-97.

10. Rekittke J, Lin E (2014) La senda de Singapour. Revista de paisajismo, Paisea, 30: 90-95.

11. Benedict MA, McMahon ET (2006) Green Infrastructure. Linking landscapes and Communities. Washington, USA.

12. Demuzere M, Orru K, Heidrich O, Olazabal E, Geneletti D, et al. (2014) Mitigating and adapting to climate change: Multi-functional and multiscale assessment of green urban infrastructure. J Environ Manage 146: 107-115.

13. Mathey J, Röbler S, Banse J, Lehmann I, Bräuer A (2015) Brown fields as an element of green infrastructure for implementing ecosystem services into urban areas. Journal of Urban Planning and Development 141(3).

14. Ahern J (1995) Greenways as a planning strategy. Landscape and urban planning 33(1): 131-155.

15. Fábos JG, Ryan RL (2004) International greenway planning: an introduction. Landscape and urban planning 68(2): 143-146.
16. Opdam P, Steingröver E, Van Rooij S (2006) Ecological networks: a spatial concept for multi-actor planning of sustainable landscapes. Landscape and urban planning 75(3-4): 322-332.

17. Steiner F (2000) The living landscape. In: An Ecological Approach to Landscape Planning. McGraw Hill, New York, USA.

18. McKinney ML (2002) Urbanization, biodiversity, and conservation. Bioscience 52(10): 883-890.

19. Farina A (2000) Landscape ecology in action. Kluwer Academic Publisher, US.

20. Bennett AF (1999) Linkages in the Landscape: The Role of Corridors and Connectivity in Wildlife Conservation (Gland: IUCN).

21. MacArthur RH, Wilson EO (2015) Theory of Island Biogeography. (MPB-1) Princeton University Press, US. (Vol.1).

22. Robinson T (2006) Proceedings of landscape character \& green infrastructure workshop 16 May 2006, Winter-hill Conference Centre, Milton Keynes.

23. Walmsley A (2006) Greenways: Multiplying and diversifying in the $21^{\text {st }}$ century. Landscape and Urban Planning 76: 252-290.

24. Kennedy C, Wilkison JB, Balch J (2003) Conservation thresholds for land use planners. Environmental Law Institute, Washington DC.

25. Flink CA, Searns RM (1993) Greenways: a guide to planning, design and development. Washington.

26. Turner T (2006) Greenway planning in Britain: recent work and future plans. Landscape and urban planning 76(1): 240-251.

27. Little CE (1990) Greenways for America. Baltimore, Johns Hopkins University Press, US.

28. President's Commission on Americans Outdoors (1987) The Report of the President's Commission on Americans Outdoors: The Legacy, the Challenge. Island Press, Washington, USA.

29. Toccolini A, Fumagalli N, Senes G (2006) Greenways planning in Italy: the Lambro River Valley Greenways System. Landscape and Urban Planning 76: 98-111.

30. Fumagalli N, Toccolini A (2012) Relationships between Greenways and Ecological Network: a case study in Italy. Int. J. Environ. Res 6(4): $903-$ 916.

31. Meerow S, Newell JP (2017) Spatial planning for multifunctional green infrastructure: Growing resilience in Detroit. Landscape and Urban Planning 159: 62-75.

32. Konkoly GE, Nagy D (2010) A concept and case study of ecological network planning in the Fertö-Hanság basin in Hungary (Paper presented at Fábos Conference on Landscape and Greenway Planning, Budapest.

33. Turner T (1998) Landscape Planning and Environmental Impact Design. London.

34. Jongman RHG, Pungetti G (2004) Ecological Networks and Greenways: concept, design, implementation. Cambridge, Cambridge University Press.

35. Opdam P (1991) Metapopulation theory and habitat fragmentation: a review of holarctic breeding bird studies. Landscape ecology 5(2): 93106. 
This work is licensed under Creative

Commons Attribution 4.0 License

DOI:10.19080/ARTOAJ.2017.12.555833
Your next submission with Juniper Publishers will reach you the below assets

- Quality Editorial service

- Swift Peer Review

- Reprints availability

- E-prints Service

- Manuscript Podcast for convenient understanding

- Global attainment for your research

- Manuscript accessibility in different formats ( Pdf, E-pub, Full Text, Audio)

- Unceasing customer service

Track the below URL for one-step submission https://juniperpublishers.com/online-submission.php 